\begin{tabular}{|ll}
\hline Received & $: 15$ Maret 2020 \\
Revised & $: 2$ April 2020 \\
Accepted & $: 20$ April 2020 \\
Online & $: 25$ April 2020 \\
Published & $: 30$ April 2020
\end{tabular}

\title{
Kelayakan Media Pembelajaran Monopoli pada Materi Struktur dan Fungsi Jaringan Tumbuhan
}

\author{
Fitri Andriyani ${ }^{1}$, Rahma R. Saraswati ${ }^{2}$, a), Dina Melasari ${ }^{3}$, Agustiani Putri ${ }^{4}$, \\ Dadan Sumardani ${ }^{5}$ \\ ${ }^{1,3}$ Program Studi Pendidikan Biologi, FMIPA, Universitas Negeri Jakarta \\ ${ }^{2,4}$ Program Studi Pendidikan Matematika, FMIPA, Universitas Negeri Jakarta \\ ${ }^{5}$ Program Studi Pendidikan Fisika, FMIPA, Universitas Negeri Jakarta \\ : rahma.rosaliana@gmail.com
}

\begin{abstract}
The classic mistake that always arises in understanding biology is that many consider biology a material that must be memorized, so that for some students consider biology to be a boring subject. In addition, according to the results of an interview with one of the science teachers, stated that at the branch biology, material structure and function of plant tissue is one of the most difficult material for students to understand. This is because studying this material in detail requires aids (microscopes) whose observations are not necessarily easily understood by students. In addition, so far the learning media and methods used are less varied. Based on the above statement, we need a learning media that can increase student interest and student understanding in learning the structure and function of plant tissue. So this study aims to determine the feasibility of monopolistic learning media on the structure and function of tissue in plants. The method used in this research is quantitative research with statistics. Based on the questionnaire test of eighth grade students of Al-Hasani MTs, it was found that the average value of the feasibility analysis was $90,27 \%$ which was classified as very good.
\end{abstract}

Keywords: Learning Media, Monopoly, Biology.

\begin{abstract}
Abstrak
Kesalahan klasik yang selalu muncul dalam memahami mata pelajaran biologi adalah karena banyak peserta didik menganggap biologi sebagai pelajaran yang membosankan.Selain itu, menurut hasil wawancara dengan salah satu guru IPA, menyatakan bahwa pada cabang ilmu biologi materi struktur dan fungsi jaringan tumbuhan adalah salah satu materi yang paling sulit dipahami oleh siswa. Hal ini dikarenakan mempelajari materi ini secara detail memerlukan alat bantu (mikroskop) yang hasil pengamatannya belum tentu mudah dipahami oleh siswa. Selain itu, selama ini media pembelajaran yang digunakan kurang bervariasi. Berdasarkan pernyataan di atas, maka diperlukan sebuah media pembelajaran yang dapat meningkatkan ketertarikan siswa dan pemahaman siswa dalam mempelajari materi struktur dan fungsi jaringan tumbuhan. Maka penelitian ini bertujuan untuk mengetahui tingkat kelayakan media pembelajaran monopoli terhadap materi struktur dan fungsi jaringan pada tumbuhan. Metode yang digunakan dalam penelitian ini adalah penelitian kuantitatif dengan statistika. Berdasarkan hasil kuisioner terhadap siswa kelas VIII MTs Al-Hasani maka didapatkan nilai rata-rata dari analisis kelayakan adalah $90,27 \%$ yang tergolong sangat baik.
\end{abstract}

Kata Kunci : Media Pembelajaran, Monopoli, Biologi. 


\section{PENDAHULUAN}

Ilmu Pengetahuan Alam (IPA) adalah ilmu yang mempelajari peristiwa - peristiwa yang terjadi di alam, IPA tidak hanya mengumpulkan pengetahuan melainkan juga memerlukan kerja, cara berpikir, dan cara memecahkan masalah (Siutriani, dkk., 2016). Salah satu cabang yang dipelajari dalam mata pelajaran IPA adalah biologi. Ilmu biologi adalah ilmu yang mempelajari segala hal yang berhubungan dengan kehidupan dan makhluk hidup. Pembelajaran biologi di sekolah menengah pertama diharapkan siswa dapat mempelajari diri sendiri dan alam sekitar, serta prospek pengembangannya dalam kehidupan sehari-hari.

Permasalahan mendasar yang sering muncul di sekolah adalah metode pembelajaran biologi yang didominasi ceramah (Maskur,dkk., 2018). Selain itu, dalam memahami mata pelajaran biologi, banyak siswa yang menganggap biologi sebagai pelajaran yang membosankan (Kusnawati, 2003 dalam Andriyani, dkk., 2020). Menurut hasil wawancara dengan salah satu guru IPA, menyatakan bahwa pada cabang ilmu biologi, salah satu materi yang paling sulit dipahami oleh siswa adalah materi struktur dan fungsi jaringan tumbuhan. Hal ini dikarenakan mempelajari materi ini memerlukan bantuan mikroskop, yang belum tentu mudah dipahami oleh siswa hasil pengamatannya.

Pernyataan tersebut menunjukkan bahwa perlunya sebuah media pembelajaran yang dapat memotvas siswa dan mengkatkan pemahaman siswa dalam mempelajari materi ini. Media pembelajaran merupakan suatu benda yang dapat diindrai, yang berfungsi sebagai alat bantu dalam proses belajar mengajar untuk meningkatkan hasil belajar siswa, baik yang terdapat di dalam maupun di luar kelas (Nurmadiah, 2016). Pemanfaatan media yang benar dalam pembelajaran biologi merupakan salah satu solusi dari beberapa masalah yang terkait dengan motivasi dan minat belajar siswa (Emda, 2011). Salah satu metode yang tepat yaitu menjadikan permainan sebagai media pembelajaran. Permainan monopoli merupakan salah satu permainan yang terkenal di dunia. Permainan monopoli saat ini banyak dikembangkan menjadi media pembelajaran. Hasil pengembangan permainan monopoli menjadi media pembelajaran akan berbeda dengan media lain yang cenderung membosankan (Rohman dan Mutmainah, 2015).

Pada penelitian sebelumnya, pengembangan permainan monopoli menjadi media pembelajaran sudah banyak dilakukan (Purwanto, 2012; Rohman, 2015; Siskawati, 2016; Siutriani, 2016; Suciati, 2016; Susanto, 2012). Salah satunya adalah penelitian dengan pengembangan media pembelajaran monopoli pada materi biologi (Andriyani, 2020). Juga telah dilakukan penelitian pengembangan monopoli pada materi polusi udara dan mengujicobakannnya di SMP 162 Jakarta dan menghasilkan media yang baik (Rosita, 2018). Dalam penelitian ini, peneliti melakukan analisis kelayakan pada media pembelajaran monopoli pada materi struktur dan fungsi jaringan tumbuhan oleh sekolah menengah pertama. Kelayakan pada media pembelajaran monopoli pada materi struktur dan fungsi jaringan tumbuhan akan diujikan pada siswa kelas VIII MTS Al-Hasani.

\section{METODE}

Jenis penelitian ini adalah penelitian kuantitatif yaitu data-data numerikal (angka) yang diolah dengan metode statistika sangat ditekankan dalam penelitian ini. Teknik analisis data yang digunakan dalam penelitian ini menggunakan skala likert untuk mengetahui tanggapan siswa terhadap media pembelajaran ini. Untuk keperluan analisis kuantitatif, jawaban diberi skor yang telah ditentukan. Adapun penentuan kelas dapat ditentukan dengan cara menetukan nilai jangkauan yang kemudian dibagi 5. Hasilnya dapat dilihat dari Tabel 1 di bawah ini.

TABEL 1. Kategori Skor

\begin{tabular}{ll}
\hline Kategori & Skor \\
\hline Sangat Baik & 5 \\
Baik & 4 \\
Cukup & 3 \\
Kurang & 2 \\
Sangat Kurang & 1 \\
\hline
\end{tabular}

e-Journal : http://ejurnal.kpmunj.org 
Jika nilai kelayakan telah didapat maka selanjutnya adalah penunjukan predikat kualitas dari produk yang dibuat berdasarkan skala pengukuran rating scale. Skala penunjukan rating scale adalah pengubahan data kualitatif menjadi kuantitatif. Dengan rating scale data mentah yang diperoleh berupa angka yang diambil dari penjumlahan setiap butir pernyataan, kemudian ditafsirkan dalam pengertian kualitatif . Berikut tabel yang merupakan rating scale yang digunakan untuk penfsiran kelayakan produk (Tabel 2).

TABEL 2. Kategori Kelayakan Berdasarkan Rating Scale

\begin{tabular}{l|l}
\hline Rentang skor & Keterangan \\
\hline $0-25 \%$ & Sangat Tidak Layak \\
$>25 \%-50 \%$ & Kurang Layak \\
$>50 \%-75 \%$ & Cukup Layak \\
$>75 \%-100 \%$ & Sangat Layak \\
\hline
\end{tabular}

\section{HASIL DAN PEMBAHASAN}

\section{Hasil}

Secara operasional, analisis kelayakan adalah skor yang diberikan siswa dalam mengisi angket tentang kelayakan. Nilai analisis kelayakan berupa angka yang diambil dari penjumlahan setiap butir pernyataan. Angket ini diberikan kepada siswa untuk mendapatkan informasi tentang kelayakan media pembelajaran monopoli struktur dan fungsi jaringan tumbuhan. Penyusunan angket analisis kelayakan media pembelajaran monopoli struktur dan fungsi jaringan tumbuhan ini mengacu kepada indikatorindikator kelayakan media pembelajaran monopoli. Adapun kisi-kisi angket adalah sebagai berikut (Tabel 3)..

TABEL 3. Kisi-Kisi Angket Analisis Kelayakan

\begin{tabular}{|c|c|c|}
\hline Variabel & Indikator & Pertanyaan \\
\hline \multirow{9}{*}{ Kelayakan } & \multirow[t]{4}{*}{ Tampilan } & $\begin{array}{l}\text { Jenis huruf pada media } \\
\text { pembelajaran mudah dibaca. }\end{array}$ \\
\hline & & $\begin{array}{l}\text { Ukuran huruf pada media } \\
\text { pembelajaran mudah dibaca. }\end{array}$ \\
\hline & & $\begin{array}{l}\text { Bahasa yang digunakan pada } \\
\text { media pembelajaran jelas. }\end{array}$ \\
\hline & & $\begin{array}{l}\text { Tampilan gambar pada monopoli } \\
\text { ini cukup baik. }\end{array}$ \\
\hline & \multirow[t]{2}{*}{ Efisiensi } & $\begin{array}{l}\text { Media pembelajaran monopoli ini } \\
\text { sangat menarik. }\end{array}$ \\
\hline & & $\begin{array}{l}\text { Materi soal yang disajikan pada } \\
\text { monopoli ini sangat jelas. }\end{array}$ \\
\hline & \multirow[t]{3}{*}{ Interaksi } & $\begin{array}{l}\text { Saya termotivasi belajar struktur } \\
\text { dan jaringan tumbuhan karena } \\
\text { media pembelajaran ini. }\end{array}$ \\
\hline & & $\begin{array}{l}\text { Permainan ini dapat memantapkan } \\
\text { pemahaman saya tentang struktur } \\
\text { dan jaringan tumbuhan. }\end{array}$ \\
\hline & & $\begin{array}{l}\text { Saya jadi semakin menyukai } \\
\text { pelajaran IPA setelah bermain } \\
\text { dengan monopoli ini. }\end{array}$ \\
\hline
\end{tabular}


Berikut adalah hasil angket kelayakan media pembelajaran monopoli (Tabel 4).

TABEL 4. Hasil Angket Kelayakan Media

\begin{tabular}{lll}
\hline No. & Indikator & Presentase Capaian \\
\hline 1. & Tampilan & $90 \%$ \\
2. & Efisiensi & $91 \%$ \\
3. & Interaktivitas & $89,8 \%$ \\
\hline Rata - Rata & $90,27 \%$ \\
\hline
\end{tabular}

\section{Pembahasan}

Tampilan

Berdasarkan hasil data kuesioner pada tabel 4, diperoleh hasil capaian kelayakan tampilan sebesar 90\%. Berdasarkan Tabel 2. dan penelitian yang dilakukan oleh Andriyani, dkk. (2020) dapat ditarik kesimpulan bahwa tampilan media pembelajaran monopoli tergolong sangat layak karena nilai ratarata dari indikator tampilan adalah $90 \%$.

\section{Efektivitas}

Berdasarkan hasil data kuesioner pada tabel 4, diperoleh hasil capaian kelayakan efektivitas sebesar 91\%. Berdasarkan tabel 2. dan penelitian yang dilakukan oleh Andriyani, dkk. (2020) dapat ditarik kesimpulan bahwa efektivitas media pembelajaran monopoli tergolong sangat layak karena nilai ratarata dari indikator efektivitas adalah $91 \%$.

\section{Interaktivitas}

Berdasarkan hasil data kuesioner pada tabel 4, diperoleh hasil capaian kelayakan interaktivitas sebesar $89,8 \%$. Berdasarkan tabel 2. dan penelitian yang dilakukan oleh Andriyani, dkk. (2020) dapat ditarik kesimpulan bahwa interaktivitas media pembelajaran monopoli tergolong sangat layak karena nilai rata-rata dari indikator interaktivitas adalah $89,8 \%$.

\section{Kelayakan Media secara Keseluruhan}

Berdasarkan hasil data kuesioner pada Tabel 4, diperoleh hasil capaian kelayakan secara keseluruhan sebesar 90,27\%. Berdasarkan tabel 2. dan penelitian yang dilakukan oleh Andriyani, dkk. (2020) dapat ditarik kesimpulan bahwa kelayakan media pembelajaran monopoli tergolong sangat layak karena nilai rata-rata sebsar 90,27\%.

\section{KESIMPULAN}

Berdasarkan hasil penelitian, dapat disimpulkan bahwa media pembelajaran monopoli ini tergolong sangat layak. Kesimpulan tersebut diambil dari ke-3 indikator kelayakan, yaitu tampilan, efisiensi, dan interaksi nilainya berturut - turut berturut-turut adalah $90 \%, 91 \%, 89,8 \%$. sedangkan untuk nilai rata rata dari indikator tersebut adalah $90,27 \%$ itu berarti kelayakan media pembelajaran monopoli ini tergolong sangat layak. 


\section{REFERENSI}

Andriyani, F., Saraswati, R. R., Melasari, D., Putri, A., Sumardani, D. (2020). Media Pembelajaran Monopoli : Media Edukasi Materi Struktur dan Fungsi Jaringan Tumbuhan. Jurnal Pembelajaran dan Biologi Nukleus, 6(1), 81-87.

Emda, A. (2011). Pemanfaatan Media Dalam Pembelajaran Biologi Di Sekolah. Jurnal Ilmiah Didaktika, 12(1), 149.

Maskur, R., Supriyadi, S., \& Mutiara, E. B. (2018). Model Lembar Kerja Peserta Didik Berbasis Guided Inquiry Laboratory Untuk Pembelajaran Biologi. Lectura : Jurnal Pendidikan.

Nurmadiah, N. (2016). Media Pendidikan. Al-Afkar : Jurnal Keislaman \& Peradaban.

Purwanto, M., Sari, I. M., \& Husna, H. N. (2012). Implementasi Permainan Monopoli Fisika Sebagai Media Pembelajaran Dalam Pembelajaran Kooperatif Tipe TGT Untuk Meningkatkan Prestasi Belajar Dan Mengetahui Profil Kemampuan Berpikir Kritis Siswa Smp. Jurnal Pengajaran Matematika Dan Ilmu Pengetahuan Alam, 17(1), 69.

Rohman, M. A., \& Mutmainah, S. (2015). Pengembangan Media Permainan Monopoli dalam Pembelajaran Seni Budaya dan Keterampilan Kelas VI SDN Tanamera I. Jurnal Pendidikan Seni Rupa, 3(1), 47-56.

Rosita, Aisah, S., \& Ajie S. (2018). Monopoli Polusi Sebagai Media Pembelajaran Dalam Materi Polusi Udara Untuk Siswa Kelas VII SMP Negeri 162. Risenologi, 3(1), 27-30.

Siskawati, M., Pargito, P., \& Pujiati, P. (2016). Pengembangan Media Pembelajaran Monopoli Untuk Meningkatkan Minat Belajar Geografi Siswa. Jurnal Studi Sosial, 4(1), 72-80.

Siutriani, N. W., Arini, N. W., \& Garminah, N. N. (2016). Penerapan Model Course Review Horay Berbantuan Media Monopoli Untuk Meningkatkan Keaktifan Dan Hasil Belajar Ipa. E-Journal PG PAUD Universitas Pendidikan Ganesha, 4(1), 1-10.

Suciati, S., Septiana, I., Fita, M., \& Untari, A. (2016). Efektivitas Media Monopoli Berbahasa (Monosa) Dalam. 3(2), 136-150.

Susanto, A., Raharjo, \& Prastiwi, M. S. (2012). Permainan Monopoli sebagai Media Pembelajaran Sub Materi Sel pada Siswa SMA Kelas XI IPA. BioEdu 1(1). 